\title{
Стратегічний менеджмент неолімпійського спорту (на прикладі сумо)
}

\author{
Анастасія Бондар \\ Руслан Байрамов
}

Харківська державна академія фрізичної культури,

Харків, Україна

Мета: визначити стратегію розвитку сумо в Харківській області.

Матеріал і методи: проаналізовано Статут громадської організації «Харківська обласна фредерація сумо» та Національну стратегію з оздоровчої рухової активності в Україні на період до 2025 року «Рухова активність - здоровий спосіб життя-здорованація» (2016), системнийаналізтаметодмоделюваннядавможливістьпобудуватистратегічнумодель розвитку сумо у Харківській області, соціологічне опитування серед жителів Харківської області сприяло визначенню думки населення щодо сумо та перспектив його розвитку у нашому регіоні, метод експертних оцінок використано для оцінки розробленого в ході дослідження перспективного плану розвитку сумо в Харківській області.

Результати: у ході дослідження визначено, що сумо притаманні ознаки європейської моделі профресійного спорту: відсутність чіткого поділу між аматорським і професійним напрямом; спортивно-комерційна спрямованість розвитку. Окреслено стратеаію розвитку сумо в Харківській області, подано результати попередніх досліджень щодо перспективного плану розвитку сумо та запропоновано стратегічну модель розвитку сумо, яка базується на принципах системності, науковості, цілепокладання, гуманізму, включає мережу організаційно-управлінських заходів, що зумовлюють досягнення поставлених завдань, таких як зростання популярності та конкурентоспроможностісумо; покращення спортивних результатів на міжнародних змаганнях сумо; збільшення кількості людей, які займаються сумо.

Висновки: Отримані результати доповнюють і розширюють сучасні наукові дані щодо стратегічного управління розвитком неолімпійського спорту в Україні. Розроблений перспективний план розкриває мережу заходів, які покладені в основу моделі і сприятимуть вирішенню стратегічних завдань щодо розвитку сумо в регіоні. Для ефективного виконання перспективного плану ми пропонуємо Громадській організації «Харківська обласна фредерація сумо» створити структурний підрозділ «Центр розвитку сумо» зі статусом Юридичної особи, для проведення власної господарської діяльності, що передбачена статутом Федерації та не суперечить діючому законодавству, на який покласти обов'язки роботи із зовнішніхзв'язківтамаркетингу. На базіЦентрустворити структурніпідрозділи, яківідповідатимуть окремим напрямкам роботи: «Спортивний комплекс», «Академія сумо», «Музей сумо», «Спортивний магазин», «Відділ маркетингу», «Видавництво» (або видавничий відділ). Запропонована нами стратегічна модель, з урахуванням внутрішніх $i$ зовнішніх ризиків, відображає розвиток неолімпійського спорту, зокрема сумо, ефективний менеджмент сприятиме вирішенню нагальних завдань на кожному етапі та досягненню генеральної мети.

Ключові слова: сумо, стратегія розвитку, план, модель, федерація, центр розвитку сумо.

\section{Вступ}

Сумо набуває все більшої популярності в світі [10, 11], незважаючи на те, що цей вид спорту не входить до програми Олімпійських ігор. Він приваблює своїми стародавніми традиціями, видовищністю та ефективним впливом на всебічний розвиток займаючихся, про що у своїх наукових працях зазначали Безкоровайний С., Буравцов В., Коробко С., Яременко В., Малинський І., Колос М., Шандригось В. Ефективне управління розвитком даного виду спорту сприятиме його подальшій популяризації в нашій країні, збільшенню кількості займаючихся, вдосконаленню системи спортивних змагань та високим досягненням вітчизняних спортсменів на міжнародній арені.

Ефективне управління, на думку Пащенко О. [9] передбачає стратегічне планування, де стратегія визначається головною ціллю та проміжними цілями, які дозволяють її досягти. У своїх дослідженнях Кіш Г. [7] відмічав, щопроцес стратегічного планування можна представити у вигляді таких послідовних етапів: стратегічний аналіз; вибір стратегії; реалізація стратегії; моніторинг та оцінювання стратегії. На думку автора, стратегічне планування, етапи його проведення залежать від моделі планування.

На сьогоднішній день лише не велика кількість робіт вітчизняних вчених присвячена моделюванню у сфрері фрі- зичної культури та спорту, зокрема Вавренюк С. [6] у своїх дослідженнях обґрунтував структурно-функціональну модель системи державного управління розвитком фізичної культури і спорту в Україні, стратегічна мета якої полягає в підтримці належного рівня фрункціонування такої галузі, забезпеченні достатніх умов для поступального її вдосконалення на основі врахування перспективних запитів та потреб суспільства. Нерода Н. [8] проводила порівняльний аналіз моделей професійного спорту деяких країн світу, які можуть лягти в основу вітчизняної моделі. Отже відсутність наукових робіт присвячених стратегічному менеджменту неолімпійського спорту і обумовила вибір теми дослідження.

Мета дослідження - визначити стратегію розвитку сумо в Харківській області.

\section{Матеріал і методидослідження}

У дослідженні використано комплекс методів, адекватних поставленій меті, зокрема аналіз літературних джерел застосовано для визначення ступеню вивчення досліджуваної проблеми, окреслення мети та завдань дослідження, аналіз документів дав можливість вивчити Статут громадської організації «Харківська обласна феедерація сумо» та нормативно-правові документи, що ре- 


\section{СЛОБОЖАНСЬКИЙ НАУКОВО-СПОРТИВНИЙ ВІСНИК:}

\section{Матеріали XIX Міжнародної науково-практичної конференції «Фізична культура, спорт і здоров'я: стан, проблеми та}

гламентують розвиток сфери фрізичної культури та спорту, серед яких Національна стратегія з оздоровчої рухової активності в Україні на період до 2025 року «Рухова активність - здоровий спосіб життя - здорова нація» (2016), на підставі системного аналізу та завдяки методу моделювання неолімпійський спорт розглянуто як цілісну систему та побудовано стратегічну модель розвитку сумо у Харківській області, опитування (анкетування) проводилося серед жителів Харківської області з метою визначення ставлення населення до сумо та перспектив його розвитку у нашому регіоні, у опитуванні (анкетуванні) взяло участь 230 осіб віком від 17 до 55 років, тип вибірки випадковий, розрахунок вибірки проведено за стандартною методикою, метод експертних оцінок використано для оцінки розробленого в ході дослідження перспективного плану розвитку сумо в Харківській області.

\section{Результати дослідження}

Попередніми дослідженнями встановлено, що на сьогоднішній день у нашій країні сумо активно розвивається завдяки діям громадських органів управління, таких як Спортивний комітет України, Федерація сумо України, обласні та міські федерації, вітчизняні спортсмени демонструють стабільно високі результати на міжнародних змаганнях, поступово збільшується кількість дітей та підлітків залучених до занять цим видом спорту. Опитування серед населення показало, що $40,5 \%$ респондентів вважають, що на сьогоднішній день сумо не $є$ популярним видом спорту в нашій країні, але стрімко розвивається, при цьому 96\% опитаних, зійшлися на думці, що найефективнішим способом його розвитку $є$ відкриття відділень 3 сумо у дитячо-юнацьких спортивних школах [1].

Розвитком сумо в Харківській області, на сьогоднішній день, опікується Громадська організація «Харківська обласна федерація сумо», створена у 2009 році. У Харківській області сумо займаються 94 особи, 50 з яких є членами відокремленого підрозділу національної спортивної фредерації, тренувальні заняття проводять 9 працівників фрізичної культури і спорту: 4 штатні тренери з видів спорту, тренери-викладачі, викладачі зі спорту та 5 тренерів відокремленого підрозділу національної спортивної феедерації, 1 з яких має звання Заслужений тренерУкраїни. Серед харківських спортсменів 11 членів національної збірної команди України з сумо, чемпіони і призери міжнародних змагань [3]

У Харківській області щорічно, згідно з Календарями Федерації сумо України, проводяться усі навчальнотренувальні збори вітчизняних сумоїстів із спеціальної підготовки, зокрема у 2017 проведено 7 зборів, у 2018 році - 10, у 2019 році також заплановано 10 навчальнотренувальних зборів із спеціальної підготовки до змагань різного масштабу, у тому числі Всесвітніх ігор, чемпіонату світу серед дорослих та юніорів, чемпіонату Європи, Кубку Світу, Кубку Європи, Міжнародних рейтингових турнірів та ін. [4]. При цьому Харківська обласна федерація сумо не має власного спортивного залу для проведення тренувальних занять, зборів та змагань, для цього використовуються орендовані приміщення на базі дитячо-юнацьких спортивних шкіл та спортивних клубів.

За оцінками фахівців сфери фрізичної культури та спорту, найбільші можливості для подальшого розвитку фредерації відкриває популяризація сумо серед населення та розширення асортименту послуг самої фредерації, підвищення якості та реклама власних послуг, а також законодавчі зміни. Натомість найбільшу загрозу для розвитку федерації складає підвищення рівню смертності серед населення, рівень інфляції та політичні зміни в каїні, дещо менший негативний вплив на розвиток федерації має зміна рівню доходів та уподобань населення щодо виду спорту [2].

На думку жителів Харківської області, для розвитку сумо слід активізувати маркетингову діяльність обласної Федерації, збільшити кількість трансляцій змагань пізнавально-розважальних програм про сумо на телебаченні та створити офріційні сайти фредерацій і клубів у мережі Інтернет і сторінки у соціальних мережах, при цьому найменш ефективними, на думку респондентів, $є$ шляхи втілення сумо за допомогою державних важелів, як то впровадження сумо у закладах освіти та фінансування виду спорту з державного бюджету [5].

Враховуючи результати опитування населення та оцінки фахівців сфери фрізичної культури та спорту, спираючись на Національну стратегію з оздоровчої рухової активності в Україні на період до 2025 року «Рухова активність - здоровий спосіб життя - здорова нація», схваленої Указом Президента України від 9 лютого 2016 року № 42/2016, нами розроблено Перспективний план розвитку сумо в Харківській області (далі План) [1]. План включає завдання, показники, заходи, терміни виконання. Основними завданнями, які передбачені Планом, є:

1. Координація дій Федерації з органами державної влади у сфері фрізичної культури та спорту та фрізкультурноспортивними організаціями.

2. Створення інфраструктури спортивних споруд для занять сумо.

3. Формування системи знань у населення щодо оздоровчих та виховних цінностей сумо.

4. Збільшення кількості загальнодоступних спортивних заходів з сумо для залучення широких верст населення.

5. Впровадження сумо у навчальний процес та позакласну роботу з фрізичного виховання в закладах загальної середньої освіти та закладах вищої освіти (розроблення методичних рекомендацій, поліпшення матеріальнотехнічного забезпечення).

6. Впровадження у засобах масової інформації реклами фрізкультурно-спортивних заходів 3 сумо, а також пізнавальних програм про сумо для осіб різного віку.

7. Зміцнення кадрового потенціалу.

За оцінками експертів, найбільший вплив на розвиток сумо в Харківській області матимуть заходи спрямовані на створення інфраструктури спортивних споруд для занять сумо. Найвищий бал експерти-практики поставили показникам щодо координації дій громадської організації «Харківська обласна фредерація сумо» з органами державної влади у сфері фрізичної культури та спорту та фізкультурноспортивними організаціями, а дещо нижче (4,6 балів) оцінили впровадження сумо у навчальний процес та позакласну роботу 3 фізичного виховання в закладах освіти та заходи щодо зміцнення кадрового потенціалу. У свою чергу, експерти-науковці, теж на 4,6 балів оцінили заходи щодо зміцнення кадрового потенціалу, а впровадженню сумо у навчальний процес та позакласну роботу 3 фізичного виховання в закладах освіти поставили 3,9 балів, найменший вплив на розвиток сумо у Харківській області, на думку експертів-науковців, матимуть заходи, спрямовані на формування у населення системи 


\section{СЛОБОЖАНСЬКИЙ НАУКОВО-СПОРТИВНИЙ ВІСНИК:}

\section{Матеріали XIX Міжнародної науково-практичної конференції «Фізична культура, спорт і здоров'я: стан, проблеми та перспективи»}

знань щодо оздоровчих та виховних цінностей сумо $(3,8$ балів). Розроблений Планє ефективним, айого реалізація сприятиме громадській організації «Харківська обласна фредерація сумо» створити необхідні умови для залучення широких верств населення до занять сумо. Це підтверджується високою оцінкою експертів, яка становить 4,55 балів, з 5 можливих, коефіцієнт кореляції становить 0,96, що свідчить про узгодженість думок експертів [1]

У ході дослідження з'ясовано, що для сумо в Україні притаманні ознаки європейської моделі професійного спорту [8], зокрема відсутність чіткого поділу між аматорським і професійним напрямом; спортивно-комерційною спрямованістю розвитку, де діяльність спортсменів здійснюється в суто спортивних інтересах і не має на мет одержанняприбутку, навідміну від комерційно-спортивної спрямованості, яка притаманна американській моделі спорту.

Враховуючи вищезазначене, нами розроблено стратегічну модель розвитку сумо у Харківській області (рис.1), яка спирається на принципи системності, науковості, цілепокладання, гуманізму і включає мережу організаційноуправлінських заходів, що зумовлюють досягнення поставлених завдань, таких як зростання популярності та конкурентоспроможності сумо; покращення спортивних результатів на міжнародних змаганнях сумо; збільшення кількості людей, які займаються сумо.

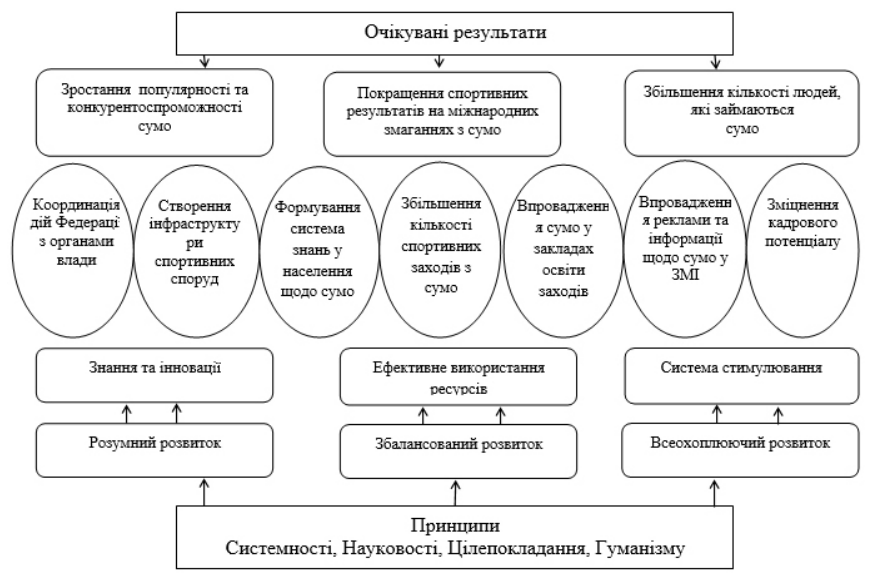

Рис. 1. Стратегічна модель розвитку сумо в Харківській області

Як зазначалося вище, основною організацією, яка створена з метою об'єднання громадян для сприяння розвитку сумо в місті Харкові та Харківській області $\epsilon$ Громадська організація «Харківська обласна федерація сумо» (далі Федерація). Новим є те, що ми пропонуємо Федерації створити в межах статуту структурний підроз діл - «Центр розвитку сумо» (далі Центр), на який поклас ти обов'язки роботи із зовнішніх зв'язків та маркетингу Оскільки зусилля Федерації щодо сприяння розвитку сумо спрямовані на виконання її основних функцій, таких як популяризація сумо серед населення, організація та проведення змагань та тренувальних зборів, формування збірних команд, та ін. (згідно статуту), саме тому, ми пропонуємо для концентрації та примноження матеріальнотехнічних, кадрових, інформаційних ресурсів створити Центр, який буде знаходитися у підпорядкуванні Федерації, але мати статус Юридичної особи, для проведення власної господарської діяльності, що передбачена статутом Федерації та не суперечить діючому законодавству Центр має розташовуватися у місті Харкові у окремій. тренувальні заняття та змагання з сумо. На території Центру (або в орендованих Центром приміщеннях) мають бути розташовані його структурні підрозділи, а came:

1. «Спортивний комплекс» із спортивним залом для змагань і необхідними приміщеннями та умовами для учасників змагань та глядачів;

2. «Академія сумо», мета якої - розвиток дитячоюнацького сумо, підготовка та підвищення кваліфікації суддів та тренерів з сумо;

3. «Музей сумо» де представити надбання попередніх років з історії розвитку сумо в місті Харкові та Харківській області;

4. «Спортивний магазин» (у тому числі Інтернетмагазин) з продажу атрибутики, літератури, спеціального спортивного одягу та харчування, обладнання та інвентарю для занять та змагань з сумо

5. «Відділ маркетингу» для зв'язків із громадськістю та населенням, вивчення попиту на послуги, які надаватимуть Федерація та Центр, розповсюдження реклами та інформації мотиваційного характеру для заохочення населення до занять сумо та відвідування змагань

6. «Видавництво» (або видавничий відділ) для випуску спеціальної літератури, друкованих рекламних та агітаційних матеріалів щодо сумо.

Для Федерації, в умовах реалізації стратегічних завдань, важливим $€$ формування надійної репутації, створення привабливого іміджу, отримання додаткових джерел фінансування, при цьому ії̈ діяльність залежить від таких фракторів, як зовнішні та внутрішні ресурси (або середовище), попит на послуги або популярність виду спорту, злагодженість взаємодії з державними та громадськими органами влади, іншими організаціями та установами. Окрім внутрішніх ризиків, існують і інтегральні ризики в контексті розвитку нашої країни, які треба враховувати при плануванні роботи Федерації, такі як неефективність державного управління; недосконалість законодавчої бази; політична та економічна криза критичні масштаби й темпи втрати людського капіталу Завдяки ефективному менеджменту та стратегічному плануванню можна подолати усі ці виклики, які стоять сьогодні перед Федерацією на шляху розвитку сумо в Харківській області і Україні в цілому.

\section{Висновки /Дискусія}

Слід зазначити, що питання стратегічного менеджменту неолімпійського спорту до сьогоднішнього дня за- лишаються не достатньо вивченими, не зважаючи на те, що неолімпійський спорт вже став предметом окремих наукових досліджень, таких авторів як О. Борисова (2013, 2016), Н. Долбишева (2014, 2015 2016, Є. Імас (2016), С. Матвеєв (2016), Е. Саварец (2012). У своїх роботах автопи вивчали особливості формування неолімпійського спорту в світі та Україні, структуру органів управління неолімпійським спортом, особливості проведення міжнародних спортивних змагань, досвід участі вітчизняних спортсменів у них, систему ресурсного забезпечення та ін. Лише у статті Я Леонова та Г. Путятіної (2014) окреслено стратегічн перспективи розвитку неолімпійського спорту в Україні, серед яких автори виділяють вдосконалення нормативно-правового, науково-методичного та медикобіологічного забезпечення системи підготовки 


\section{СЛОБОЖАНСЬКИЙ НАУКОВО-СПОРТИВНИЙ ВІСНИК:}

\section{Матеріали XIX Міжнародної науково-практичної конференції «Фізична культура, спорт і здоров'я: стан, проблеми та}

спортсменів; оптимізацію управління діяльністю організацій у системі підготовки спортсменів; активізацію економічної діяльності; інноваційний розвиток ресурсного забезпечення; інтеграцію неолімпійського спорту до міжнародного співтовариства; проведення фундаментальних та прикладних досліджень з проблем визначення та вдосконалення ресурсного потенціалу суб'єктів неолімпійського спорту.

Враховуючи те, що стратегічне планування - це процес, завдяки якому здійснюються розроблення та коригування системи формалізованих планів, фрормування переліку та змісту заходів щодо їх виконання на основі безперервного контролю та оцінки змін, які відбуваються зовні та всередині [7], у ході дослідження нами розроблено перспективний план та стратегічну модель розвитку сумо в Харківській області. Перспективний план розкриває мережу заходів, які покладені в основу моделі і сприятимуть вирішенню стратегічних завдань щодо розвитку сумо в регіоні, зокрема зростання популярності та конкурентоспроможності сумо, покращення спортивних результатів наміжнародних змаганнях, збільшення кількості людей, які займаються сумо. Для ефрективного виконання перспективного плану ми пропонуємо Громадській організації «Харківська обласна федерація сумо» створити структурний підрозділ «Центр розвитку сумо» зі статусом Юридичної особи, для проведення власної господарської діяльності, що передбачена статутом Федерації та не суперечить діючому законодавству, на який покласти обов'язки роботи із зовнішніх зв'язків та маркетингу. На базі Центру ми пропонуємо створити структурні підрозділи, які відповідатимуть окремим напрямкам роботи:

«Спортивний комплекс», «Академія сумо», «Музей сумо», «Спортивний магазин», «Відділ маркетингу», «Видавництво» (або видавничий відділ).

Запропонована нами стратегічна модель, 3 урахуванням внутрішніх і зовнішніх ризиків, відображає розвиток неолімпійського спорту, зокрема сумо, у Харківській області, при цьому, ефективний менеджмент сприятиме вирішенню нагальних завдань на кожному етапі та досягненню генеральної мети.

Перспективи подальших досліджень у цьому напрямку полягають у науковому обґрунтуванні економічної ефективності неолімпійського спорту у Харківській області.

Конфрлікт інтересів. Автори заявляють, що немає конфлікту інтересів, який може сприйматися таким, що може нанести шкоду неупередженості статті. Джерела фрінансування. Ця стаття не отримала фрінансової підтримки від державної, громадської або комерційної організації.

Список посилань

1.Байрамов, Р.(2019), "Перспективи розвитку сумо в Харківській області". Науковий часопис Нац. пед. ун-т ім. М.П. Драгоманова. Серія 5. Педагогічні науки: реалії та перспективи. Вип. 69. С.10-13.

2.Байрамов, Р.(2019), "Популяризація сумо в Україні". Науковий часопис Нац. пед. ун-т ім. М.П. Драгоманова. Серія 5. Педагогічні науки: реалії та перспективи. Вип. 68. С.12-16.

3.Байрамов, Р., Бондар, А. (2019), "Організаційно-управлінські засади діяльності Харківської обласної федерації сумо". Слобожанський науково-спортивний вісник,. № 3(71). C. 26-31. DOI: https://doi.org/10.15391/snsv.2019-3.004

4.Байрамов, Р.Х., Бондар, А.С., Котляр, С.М., Кандращенко, С.М. (2018), "Менеджмент неолімпійського спорту (на прикладі сумо)". Стратегічне управління розвитком фрізичної культури і спорту. С. 123-126

5.Бондар, А.С. (ред.) (2017), Організаційно-управлінські умови розвитку неолімпійського спорту на Слобожанщині: монографія, Харків.

6.Вавренюк, С. А. (2014), "Структурно-функціональна модель системи державного управління розвитком фрізичної культури і спорту в Україні". Інвестиції: практика та досвід. №2. Режим доступу: http://repositsc.nuczu.edu.ua/handle/123456789/2321 7.Кіш, Г.В. (2015), "Моделі стратегічного планування як інструменту управління національної економіки", https://dspace.uzhnu. edu.ua/jspui/bitstream/lib/22662/1/

8.Нерода, Н. (2016), "Характеристика європейської моделі професійного спорту та її відмінності від американської". Спортивна наука України. №2 (72). С. 68-72

9.Пащенко, О.П. (2011), "Стратегічне управління розвитком підприємства". Вісник Хмельницького національного університету Серія: Економічні науки. № 2, т. 2. С. 99-103.

10. All about sumo (2019). Nihon Sumo Kyokai Official Grand Sumo, available at : www.sumo.or.jp/EnSumoDataRikishi/search/ (accessed 10 November2019)

11. International sumo federation (2019). "International Sumo Federation Regulations On Refereeing", available at : http://www.ifssumo.org/ (accessed 10 November 2019)

Стаття надійшла до редакції: 11.11 .2019 p

Опубліковано: 30.12.2019 р.

Аннотация. Анастасия Бондарь, Руслан Байрамов. Стратегический менеджмент неолимпийского спорта (на примере Сумо) Цель: определить стратеаию развития сумо в Харьковской области. Материал и методы: проанализированы Устав общественной организации «Харьковская областная федерация сумо» и Национальную стратегию по оздоровительной двигатель- ной активности в Украине на период до 2025 года «Двигательная активность - здоровый образ жизни - здоровая нация» (2016), системный анализ и метод моделирования позволил построить стратегическую модель развития сумо в Харьковской области, социологический опрос среди жителей Харьковской области способствовало определению мнения населения по сумо и перспектив его развития в нашем регионе, метод экспертных оценок использовано для оценки разработанного в ходе исследования перспективного плана развития сумо в Харьковской области. Результаты: в ходе исследования определено, что сумо присущи признаки европейской модели профрессионального спорта: отсутствие четкого разделения между любительским и профрессиональным направлением; спортивно-коммерческая направленность развития. Определены стратегии развития сумо в Харьковской области, представлены результаты предыдущих исследований по перспективным планом развития сумо и предложено стратегическую модель развития сумо, основанная на 


\section{СЛОБОЖАНСЬКИЙ НАУКОВО-СПОРТИВНИЙ ВІСНИК:}

\section{Матеріали XIX Міжнародної науково-практичної конференції «Фізична культура, спорт і здоров'я: стан, проблеми та перспективи»}

принципах системности, научности, целеполагания, гуманизма, включая сеть организационно-управленческих мероприятий, обусловливающие достижение поставленных задач, таких как рост популярности и конкурентоспособности сумо; улучшение спортивных результатов на международных соревнованиях сумо; увеличение количества людей, которые занимаются сумо. Выводы: Полученные результаты дополняют и расширяют современные научные данные по стратегическому управлению развитием неолимпийскому спорта в Украине. Разработанный перспективный план раскрывает сеть мероприятий, которые положены в основу модели и способствовать решению стратегических задач по развитию сумо в регионе. Для эффективного выполнения перспективного плана мы предлагаем Общественной организации «Харьковская областная фредерация сумо» создать структурное подразделение «Центр развития сумо» со статусом юридического лица, для проведения собственной хозяйственной деятельности, предусмотренной уставом Федерации и не противоречащей действующему законодательству, на который возложить обязанности работы по внешним связям и маркетинга. На базе Центра создать структурные подразделения, отвечающие отдельным направлен ям работы: "Спортивный комплекс», "Академия сумо», «Музей сумо», «Спортивный магазин», «Отдел маркетинга», «Издательство» (или издательский отдел). Предложенная нами стратегическая модель, с учетом внутренних и внешних рисков, отражает развитие неолимпийскому спорта, в частности сумо, эффрективный менеджмент будет способствовать решению насущных задач на каждом этапе и достижению генеральной цели.

Ключевые слова: сумо, стратегия развития, план, модель, федерация, центр развития сумо.

Abstract. Anastasia Bondar, Ruslan Bayramov. Strategic management of non-Olympic sports (on the example of Sumo). Purpose: to determine Sumo's development strategy in Kharkiv region. Material and methods: the Statute of the public organization "Kharkiv Regional Sumo Federation" and the National Strategy for Healthy Movement Activity in Ukraine for the Period up to 2025 "Motor Activity - Healthy Lifestyle - Healthy Nation" (2016) are analyzed, systematic analysis and modeling method made it possible to build a strategic model of sumo development in Kharkiv region, a sociological survey among the residents of Kharkiv region helped to determine the opinion of Sumo population and its prospects in our region, the method of expert assessments was used to evaluate the prospective sumo development plan developed during the study in the Kharkov region. Results: The results obtained complement and extend current scientific data on the strategic management of the development of nonOlympic sports in Ukraine. The outlined plan reveals a network of activities that underpin the model and will contribute to the strategic development of Sumo in the region. For effective implementation of the perspective plan we propose to the NGO "Kharkiv Regional Sumo Federation" to create a structural subdivision "Sumo Development Center" with the status of a Legal Entity, to carry out its own economic activity, which is stipulated by the Federation statute and does not contradict the current legislation, which entrust the duties of external relations and marketing. On the basis of the Center to create structural units that will meet the specific areas of work: "Sports Complex", "Sumo Academy", "Sumo Museum", "Sport Shop", "Marketing Department", "Publishing House" (or publishing department). Our strategic model, taking into account internal and external risks, reflects the development of non- Olympic sports, in particular sumo, effective management will contribute to the solution of urgent tasks at each stage and the achievement of the general goal. Conclusions: the results complement and expand the current scientific data on the development of nonOlympic sport, development of sumo, methods of teaching sumo. The research determines the development of the sumo in the Kharkiv region, the structure, directions of activity of the public organization of sporting-sports direction of the Kharkiv Regional Sumo Federation in accordance with the Charter. Polls of ordinary citizens showed that, in the opinion of most of them, the Federation should intensify its marketing activities, increase the number of TV broadcasts, create official websites of federations and clubs on the Internet. Experts' opinions confirm the opinion of citizens, the greatest opportunities for the further development of the federation opens the popularization of the sumo among the population and the expansion of the range of services of the federation itself, improving quality and advertising of their own services, as well as legislative changes. In the opinion of ordinary citizens and experts estimate, the state has the least impact on the development of sumo in our Region and on the activities of the Federation.

Keywords: sumo, development strategy, plan, model, federation, sumo development center.

\section{References}

1. Bairamov, R. (2019), "Prospects for Sumo development in Kharkiv Region". Naukovyi Chasopys Nats. Ped. Un-T Im. M.P. Drahomanova. Series 5. Pedahohichni Nauky Realii Ta Perspektyvy. Vol. 69. pp. 10-13.

2. Bairamov, R. (2019), "Promotion of Sumo in Ukraine". Naukovyi Chasopys Nats. Ped. Un-T Im. M.P. Drahomanova. Series 5. Pedahohichni Nauky Realii Ta Perspektyvy. Vol. 68. pp.12-16.

3. Bairamov, R., Bondar, A. "Organizational and managerial bases of activity of the Kharkiv Regional Sumo Federation". Slobozans'ki naukovo-sportivnij visnik. No 3(71). pp. 26-31. DOI: https://doi.org/10.15391/snsv.2019-3.004

4. Bairamov R.Kh., Bondar A.S., Kotliar S.M., Kandrashchenko S.M. (2018) "Menedzhment neolimpiiskoho sportu (na prykladi sumo)". Stratehichne upravlinnia rozvytkom fizychnoi kultury i sportu. pp. 123-126

5. Bondar, A.S. (ed.) (2017), Organizatsiyno-upravlinski umovi rozvitku neolimpiyskogo sportu na Slobozhanshchini: monografiya, [Organizational-administrative conditions for the development of non-Olympic sport in Slobozhanshchyna: monograph], Kharkiv. (in Ukr.)

6. Vavreniuk, S. A. (2014), «Structural and functional model of the system of state management of the development of physical culture and sports in Ukraine». Investytsii: praktyka ta dosvid. №2, available at : http://repositsc.nuczu.edu.ua/handle/123456789/2321 (accessed 10 November 2019)

7. Kish, H.V. (2015), «Strategic planning models as a tool of national economy management», available at : https://dspace.uzhnu.edu. ua/jspui/bitstream/lib/22662/1/ (accessed 10 November 2019)

8. Neroda, N. (2016), "Characteristics of the European model of professional sport and its difference from the American one». Sportyvna nauka Ukrainy. №2 (72). pp. 68-72

9. Pashchenko, O.P. (2011), «Strategic management of enterprise development». Visnyk Khmelnytskoho Natsionalnoho Universytetu. Seriia Ekonomichni Nauky. No 2, T.2. pp. 99-103.

10. All about sumo (2019). Nihon Sumo Kyokai Official Grand Sumo, available at : www.sumo.or.jp/EnSumoDataRikishi/search/ (accessed 10 November 2019)

11. International sumo federation (2019). «International Sumo Federation Regulations On Refereeing», available at : http://www. ifssumo.org/ (accessed 10 November 2019)

Received: 11.11.2019.

Published: 30.12 .2019 . 
СЛОБОЖАНСЬКИЙ НАУКОВО-СПОРТИВНИЙ ВІСНИК:

Матеріали XIX Міжнародної науково-практичної коноеренції «Фізична культура, спорт і здоров'я: стан, проблеми та

\section{Відомості про авторів / Information about the Authors}

Бондар Анастасія Сергіївна: к. фріз. вих., доцент; Харківська державна академія фрізичної культури: вул. Клочківська, 99, м. Харків, 61058, Україна.

Бондарь Анастасия Сергеевна: к. физ. восп., доцент; Харьковская государственная академия физической культуры: ул. Клочковская, 99, г. Харьков, Украина.

Anastasia Bondar: PhD (Physical Education and sport); Kharkiv State Academy of Physical Culture: Klochkivska str., 99, Kharkiv, 61058, Ukraine.

E-mail: anastasiabond1@ukr.net

ORCID.ORG/0000-0002-2816-498

Байрамов Руслан Халік огли: Харківська державна академія фрізичної культури: вул. Клочківська 99, м. Харків, 61058, Україна. Байрамов Руслан Халик оглы: Харьковская государственная академия физической культуры: ул. Клочковская 99, г.

Харьков, 61058, Украина.

Bairamov Ruslan Khalik ogly: PhD (Juridical), Kharkiv State Academy of Physical Culture: 99 Klochkivska Str., Kharkiv, 61058, Ukraine. ORCID.ORG/0000-0001-8204-5533 E-mail: bayramov16031990@ukr.net 